\title{
Bank Lending and Monetary Policy: Evidence from Deposit Money Banks (DMBs) in Nigeria
}

\author{
Ashamu, Sikiru $\mathrm{O}^{1}$ \\ ${ }^{1}$ Department of Banking and Finance, Faculty of Management Sciences, Lagos State University, Nigeria \\ Correspondence: Department of Banking and Finance, Faculty of Management Sciences, Lagos State University, \\ Nigeria, Tel: +2348033713969 E-mail: soyerinde2012@gmail.com
}

Received: November 20, 2017

Accepted: November 25, 2017

Online Published: January 03, 2018

\begin{abstract}
Monetary policy is aimed at attaining price stability, full employment and moderate long-term interest rates in the economy based on regulatory authority priorities, prevailing economic and financial conditions. Using annualized time series data from DMBs in Nigeria and the Vector Error Correction Model (VECM) as well as the simulates generalized impulse response functions, this study assessed the dynamic interactions between bank lending and monetary policy by observing how banks' lending patterns are influenced by changes in monetary policy over the years in Nigeria. The result revealed that bank lending responds to short run changes in monetary policy but there is no long run influence from monetary policy to bank loan as banks adjust their portfolio mix in line with the prevailing monetary policy. Similarly, it revealed that changes in monetary policy often create fluctuations on bank health and as such regulatory authority must focus on factors such as monetary policy rate and bank capital that influence bank position in order to attain a significant economic performance using banks as a monetary policy transmission mechanism to the economy.
\end{abstract}

Keywords: Bank Lending, Monetary Policy, Capital, Economy.

\section{Introduction}

In every economic setting, monetary policy is aimed at creating a functional means of managing interest and employment rate. However, the prime motive is the maintenance of price stability by the apex/regulatory bank which motivate long-term economic growth and employment (Turguttopbas, 2017). The key monetary policy components comprise Open Market Operations (OMO), discount rate and reserve requirements fixed by the central banks. The OMO involved trading activities by central banks on government financial securities at market determined prices while the discount rate represent the interest rate charged by central banks on short-term loans to depository institutions. The OMO and discount rate complements each other and serves as a buffer for commercial banks liquidity.

Thus, a reduction in the central bank discount rate is an expansionary policy because it influences other interest rates in the economy and vice versa. Similarly, the reserve requirements affect depository institution liquidity as it influence the size of fund available for money creation. A decline in the central bank stipulated reserve 
requirements is expansionary because it increases the size of funds available for onward lending to consumers and businesses in the banking system.

Consequently, the influence of monetary policy in an economy can be realized through various channels termed monetary policy transmission mechanism by various scholars such as Schneider (1998) and Van den Heuvel (2002). However, changes in monetary policy changes flows through a lag effects on price movements and several studies have analysed the effects of changes in the monetary policy rate on different financial institutions, instruments and market.

Thus, this study examines how DMBs activities reflect changes in monetary policy by examining the short and long-run relationship between bank lending and monetary policy in order to observe how banks' lending patterns are influenced by changes in monetary policy over the years in Nigeria. Similarly, this paper seeks to contribute to the capital-credit-crunch and bank-capital-channel discourse through an empirical study. The remaining segments of this study comprise brief literature review, research methods, results and conclusions.

\section{Brief Literature Review}

Several banking models as underlined the prominent role of capital in banking operation such as loan loss absorption, asymmetric information mitigation and serving as a guide for investment decision [Mankiw (1986), Bernanke \&Gertler (1987), Holmstrom \& Tirole (1997), and Meh \& Moran (2004)]. Similarly, some studies examined the influence of bank credit allocation and capital in the economy for example, Bernanke and Lown (1991) observed that bank capital positions have a significant effect on bank lending, but indifferent to employment. Peek and Rosengren (1995) perceived that a decrease in bank capital negatively affect deposits while loans would decrease due to contraction in bank capital while Hancock and Wilcox (1997) found that changes in bank capital significantly affects commercial loans, but not residential loans. Schneider (1999) studied the interaction between bank's borrowing limit and heterogeneity in borrowing and lending behaviour across banks using financial imperfection in moral hazard problem associated with entrepreneurial bankers strategic defaults. Thus, banks often hold inside capital in order to mitigate against operational based problems. Some studies examined monetary policy influence on loan growth through the monetary transmission mechanism via bank capital contraction. For example, Kishan and Opiela (2006) studied bank lending and credit channel through monetary policy and loan growth. They observed that bank loan growth are more sensitive to fluctuation in monetary policy. Similarly, Den Haan et al. (2007) showed that commercial and industrial loans increase due to contractionary monetary policy as banks adjust their loan portfolios in line with optimistic expectations in commercial loans. Gambacorta and Mistrulli (2004) and Bolton and Freixas (2006) opined that a distinct bank capital channel is essential in studying monetary transmission mechanism as bank capital serves as an important factor in monetary policy operation that may hinder or expand its effects.

Orzechowski (2016) examined the long-run relationship between federal funds rate policy, bank capital and lending at U.S. commercial banks and the results showed that banks with sufficient capital have strong relationship to changes in the federal funds rates while changes in the portfolio ratio between real estate to commercial loans is inversely related to monetary policy changes. Similarly, Turguttopbas (2017) studied various perspectives on monetary policy and cost of capital in turkey using analytical approach. The result revealed a strong co-movement between interest rates which affected the Central Bank of Turkey (CBT) lending rate in both directions. This study contributes to literature by exploring long run relation between lending and monetary policy using DMBs data in Nigeria. To best of my knowledge, the study is the first study to use long run annualized data to study banking lending vis-à-vis monetary policy in Nigeria in terms of adjustment in bank loan portfolio as a result of changes in monetary policy. 


\section{Research Methods}

In order to avoid some empirical challenges faced by earlier studies on bank lending and monetary policy, such as causality identification, banking structure, regulation accounting changes as well as disentangle supply and demand loan effects. This study uses annual time series data of all DMBs in Nigeria from 1981 to 2015. The data set were obtained from the Central Bank of Nigeria Statistical Bulletin 2015. The variables employed in the analysis comprise bank loans, monetary policy rate, liquidity ratio, capital and gross domestic product. The base line equation is based Orzechowski (2016) approach and it is calibrated as follows:

loan $=\mathrm{f}$ (monetary policy rate, liquidity ratio and gross domestic product)

\section{$\log$ loan $=\alpha+\beta \log M P R+\gamma \log L R+\theta \log$ Capital $+\delta \log G D P+e$} $-2$

Where

$$
\begin{array}{ll}
\text { Loan } & =\text { Bank Credit to Private Sector } \\
\text { MPR } & =\text { Monetary Policy Rate, } \\
\text { LR } & =\text { Liquidity Ratio } \\
\text { Capital } & =\text { DMB Capital } \\
\text { GDR } & =\text { Gross domestic product }
\end{array}
$$

The unit root test, cointegration, vector autoregression (VAR) and impulse response time-series techniques were employed in examining the long run relationship and dynamic interactions between bank capital, lending and monetary policy. The cointegration tests is a requisite test for proper VAR model specification while the impulse response functions revealed VAR results in a simple form. The analysis employ the Augmented Dickey-Fuller (ADF) and Phillips- Perron (PP) unit root tests in determining the series order of integration while the VAR-based approach to cointegration of Johansen (1988) and Johansen \& Juselius (1990) gives the nature of cointegration. Based on the results of the unit root and cointegration tests, this study VAR model is specified and estimated. The impulse-response functions generation is an innovations in VAR model used to check for contemporaneous correlation in variables as shock in one variable can correlation with changes in other variables. A famous means of resolving such identification problem is the Sims' (1980) strategy which involve orthogonalizing the innovations through the Cholesky decomposition.

\subsection{Results}

Table 1: Unit Root Result

\begin{tabular}{lcccc}
\hline Variable & \multicolumn{2}{c}{ ADF Test } & \multicolumn{2}{c}{ PP test } \\
\hline & Level & First Difference & Level & First Difference \\
\hline Loan & 0.097371 & -4.209495 & 0.052712 & -4.042368 \\
\hline MPR & -2.922254 & -6.992999 & -2.915697 & -7.138592 \\
\hline LR & -3.650755 & -6.573249 & -3.670285 & -11.78841 \\
\hline Capital & -1.033100 & -6.409620 & -1.069392 & -6.410448 \\
\hline GDP & -0.407514 & -5.359209 & -0.407083 & -5.345074 \\
\hline
\end{tabular}

Table 1 provides results from unit root tests for each of the specified variables and both the ADF and PP tests indicate non-stationarity in levels and turn stationary at first differences for all variables. This implies that these variables are integrated of order 1 or I(1) which allows for the Johansen and Juselius cointegration test whose maximal eigenvalue, trace statistics and critical value are given in Table 2 below: 


\begin{tabular}{|c|c|c|c|c|c|}
\hline & 2012 & 2013 & 2014 & 2015 & 2016 \\
\hline Population (million) & 165 & 169 & 174 & 179 & 184 \\
\hline GDP per capita (USD) & 2,708 & 2,944 & 3,182 & 2,677 & 1,976 \\
\hline GDP (USD bn) & 446 & 498 & 553 & 479 & 363 \\
\hline Economic Growth (GDP, annual variation in \%) & 4.2 & 5.5 & 6.2 & 2.8 & -1.6 \\
\hline Consumption (annual variation in \%) & 0.0 & 21.1 & 0.6 & 1.5 & - \\
\hline Investment (annual variation in \%) & 2.8 & 4.2 & 13.4 & -1.3 & - \\
\hline Industrial Production (annual variation in \%) & 1.5 & 0.0 & 5.5 & 0.3 & -5.7 \\
\hline Unemployment Rate & 7.6 & 7.1 & 4.8 & 4.3 & 5.0 \\
\hline Fiscal Balance (\% of GDP) & -1.3 & -1.4 & -0.9 & -1.6 & - \\
\hline Public Debt (\% of GDP) & 12.5 & 12.6 & 10.6 & 12.1 & 18.6 \\
\hline Money (annual variation in \%) & 16.4 & 1.3 & 20.6 & 5.9 & 16.8 \\
\hline Inflation Rate (CPI, annual variation in $\%$, eop) & 12.0 & 8.0 & 8.0 & 9.6 & 18.6 \\
\hline Inflation Rate (CPI, annual variation in \%) & 12.2 & 8.5 & 8.1 & 9.0 & 15.7 \\
\hline Policy Interest Rate (\%) & 12.00 & 12.00 & 13.00 & 11.00 & 14.00 \\
\hline Exchange Rate (vs USD) & 156.2 & 160.0 & 183.0 & 199.1 & 304.7 \\
\hline Exchange Rate (vs USD, aop) & 158.8 & 159.2 & 165.2 & 197.9 & 256.1 \\
\hline Current Account (\% of GDP) & 4.2 & 4.0 & 0.2 & -3.2 & 0.8 \\
\hline Current Account Balance (USD bn) & 18.9 & 20.1 & 1.3 & -15.4 & 2.7 \\
\hline Trade Balance (USD billion) & 40.9 & 43.8 & 21.0 & -6.4 & -0.5 \\
\hline Exports (USD billion) & 94.3 & 95.1 & 82.6 & 45.9 & 34.7 \\
\hline Imports (USD billion) & 53.4 & 51.4 & 61.6 & 52.3 & 35.2 \\
\hline Exports (annual variation in \%) & -2.9 & 0.8 & -13.2 & -44.4 & -24.4 \\
\hline Imports (annual variation in \%) & -14.1 & -3.8 & 19.9 & -15.0 & -32.7 \\
\hline International Reserves (USD) & 44.2 & 43.6 & 34.5 & 29.1 & 25.8 \\
\hline External Debt (\% of GDP) & 1.5 & 1.8 & 1.8 & 2.2 & 3.1 \\
\hline
\end{tabular}

Table 2: Cointegration Rank Test

\begin{tabular}{ccccc}
\hline \hline $\begin{array}{c}\text { Hypothesized } \\
\text { No. of CE(s) }\end{array}$ & Eigenvalue & $\begin{array}{c}\text { Trace } \\
\text { Statistic }\end{array}$ & $\begin{array}{c}\mathbf{0 . 0 5} \\
\text { Critical Value }\end{array}$ & Prob.** \\
\hline \hline None ${ }^{*}$ & 0.560786 & 72.14046 & 69.81889 & 0.0323 \\
\hline At most 1 & 0.456426 & 44.98908 & 47.85613 & 0.0907 \\
\hline At most 2 & 0.355877 & 24.87265 & 29.79707 & 0.1660 \\
\hline At most 3 & 0.261252 & 10.35711 & 15.49471 & 0.2543 \\
\hline At most 4 & 0.010993 & 0.364782 & 3.841466 & 0.5459 \\
\hline \hline
\end{tabular}

Trace test indicates 1 cointegrating eqn(s) at the 0.05 level 
The trace statistic value of 72.14 is greater than the critical value of 69.82 which implies the existence of cointegration relationship and suggests the presence of at least one unique cointegrating vector among the five variables. The cointegration result led to the lag selection, VEC model and stimulate generalized impulse-response functions to show the dynamic responses of loans to changes in other specified variables in the model.

Table 3: VAR Lag Order Selection Criteria

\begin{tabular}{ccccccc}
\hline \multicolumn{7}{c}{ Endogenous variables: LOANS MPR LR CAPITAL GDP } \\
\hline Lag & LogL & LR & FPE & AIC & SC & HQ \\
\hline 0 & 38.62021 & NA & $8.97 \mathrm{e}-08$ & -2.037589 & -1.810845 & -1.961296 \\
\hline 1 & 192.5278 & 251.8488 & $3.70 \mathrm{e}-11$ & -9.850172 & $-8.489711^{*}$ & -9.392418 \\
\hline 2 & 224.9495 & $43.22891^{*}$ & $2.64 \mathrm{e}-11^{*}$ & $-10.29997^{*}$ & -7.805792 & $-9.460756^{*}$ \\
\hline$*$ indicates lag order selected by the criterion & & & & \\
\hline
\end{tabular}

The lag selection criteria in table 3 provides the basis for determining the ideal lags selection for the study and most of the criteria such as Final Prediction Error (FPE), Akaike Information Criterion (AIC) and Hannan-Quinn information criterion (HQ) favour 2 as the ideal lag for the study.

The result of the Vector Error Correction Estimates shown in Appendix 1 and in table 4 revealed that the model coefficient value of 0.041128 and probability value of 0.6167 is positive and insignificant, this implies that there is no long run causality running from the specified variables to bank loans.

Also, the significance of each of the Vector Error Correction Estimates in italics (Appendix 1) is estimated and the result of the individual coefficient probability value and the result is presented in table 4 below:

Table 4: Result for individual coefficient probability value

\begin{tabular}{ccccc}
\hline & Coefficient & Std. Error & t-Statistic & Prob. \\
\hline $\mathrm{C}(1)$ & 0.041128 & 0.080878 & 0.508514 & 0.6167 \\
\hline $\mathrm{C}(2)$ & 0.399558 & 0.187605 & 2.129778 & 0.0458 \\
\hline $\mathrm{C}(3)$ & -0.494362 & 0.167113 & -2.958258 & 0.0078 \\
\hline $\mathrm{C}(4)$ & -0.459501 & 0.141600 & -3.245064 & 0.0041 \\
\hline $\mathrm{C}(5)$ & -0.202334 & 0.111637 & -1.812433 & 0.0850 \\
\hline $\mathrm{C}(6)$ & 0.161841 & 0.111572 & 1.450544 & 0.1624 \\
\hline $\mathrm{C}(7)$ & -0.078638 & 0.095666 & -0.822003 & 0.4208 \\
\hline $\mathrm{C}(8)$ & 0.287027 & 0.058364 & 4.917866 & 0.0001 \\
\hline $\mathrm{C}(9)$ & -0.143905 & 0.086186 & -1.669697 & 0.1106 \\
\hline $\mathrm{C}(10)$ & 0.086734 & 0.111907 & 0.775057 & 0.4474 \\
\hline $\mathrm{C}(11)$ & 0.068008 & 0.109376 & 0.621782 & 0.5411 \\
\hline
\end{tabular}




\begin{tabular}{lcccc}
\multicolumn{1}{c}{$\mathrm{C}(12)$} & 0.085092 & 0.025820 & 3.295547 & 0.0036 \\
\hline R-squared & 0.766552 & Mean dependent var & 0.100133 \\
\hline Adjusted R-squared & 0.638156 & S.D. dependent var & 0.071240 \\
\hline S.E. of regression & 0.042853 & Akaike info criterion & $\begin{array}{c}-3.18206 \\
6\end{array}$ \\
\hline Sum squared resid & & & -2.63241 \\
& 0.036728 & Schwarz criterion & 5 \\
\hline Log likelihood & & & -2.99987 \\
& 62.91305 & Hannan-Quinn criter. & 2 \\
\hline F-statistic & & & 1.909850 \\
\hline Prob(F-statistic) & 5.970209 & Durbin-Watson stat & \\
\hline
\end{tabular}

From the result in table 4 above, the coefficient of determination value of 0.7665 representing the adequacy of the model as $76.65 \%$ of variations in the loans are attributed to changes in the monetary policy rate, liquidity ratio, capital and gross domestic product. Similarly, the F-statistics ratio value of 5.9702 and probability value of 0.0002 is less than 0.05 is significant. This implies that the data is fitted. Similarly, the Durbin Watson statistic value of 1.9098 signifies the absence of autocorrelation in the data series employed in the analysis.

Table 5: Wald Test Result

\begin{tabular}{llll}
\hline Short run relation running from & \multicolumn{2}{c}{ Test Statistics } & Probability \\
\hline MPR to Loans & F-Statistic & 5.278321 & 0.0144 \\
\cline { 2 - 4 } & Chi-square & 10.55664 & 0.0051 \\
\hline LR to Loans & F-Statistic & 1.703742 & 0.2074 \\
\cline { 2 - 4 } & Chi-square & 3.407483 & 0.1820 \\
\hline Capital to Loans & F-Statistic & 20.45691 & 0.0000 \\
\cline { 2 - 4 } & Chi-square & 40.91383 & 0.0000 \\
\hline GDP to Loans & F-Statistic & 0.516394 & 0.6044 \\
\cline { 2 - 4 } & Chi-square & 1.032787 & 0.5967 \\
\hline
\end{tabular}

The Wald test result in table 5 above showed that there is a short run causality running from MPR to Loans as well as from Capital to Loans. However, there is no short run causality running from LR to Loans as well as from GDP to Loans.

Table 6: Breusch-Pagan-Godfrey Heteroskedasticity Test Result

\begin{tabular}{llll}
\hline F-statistic & $\mathbf{1 . 0 6 2 0 1 9}$ & Prob. F(15,16) & $\mathbf{0 . 4 5 1 4}$ \\
\hline Obs*R-squared & 15.96506 & Prob. Chi-Square(15) & 0.3844 \\
\hline Scaled explained SS & 6.647354 & Prob. Chi-Square(15) & 0.9667 \\
\hline
\end{tabular}

From the observed R-squared statistics of 15.965 and probability value of 0.3844 , it is evident that there is no heteroskedasticity in the residual of the model. Similarly, the Jarque-Bera value 1.6797 and probability value 0.431772 indicates that the data is normally distributed.

The generalized impulse-response result in Appendix 2 indicates that loans respond negatively to changes in MPR in a short while, but it reach a turning point from which it respond positively towards the Monetary Policy Rate (MPR) for a long period. Similarly, the loans respond positively and stable to changes in capital and GDP 
over time. However, loans respond positively to changes in liquidity ratio in shot while but it turn and respond negatively towards the liquidity ratio (LR).

\section{Conclusion}

The crucial roles of banks in economic growth and development cannot be underplay despite the adverse consequence of their failure or distress in the economy. In order to address such potential and managed the economy towards optimality, regulatory authority often adjust monetary policy towards the desired economic position. This study examines the dynamic interactions between bank loans and monetary policy in Nigeria by investigating how banks serve as a monetary policy transmission mechanism to the economy. The VEC model comprising bank loans, monetary policy rate, liquidity ratio, capital and gross domestic product was estimated and stimulated through the generalized impulse response in assessing the dynamic interaction among the specified variables.

The result supports the claim that monetary policy rate and bank capital influence bank loan in the short run but there is no long run causality running from the specified variables to bank loans. Similarly, the result revealed that the data is fitted in the model based on the coefficient of determination result. This implies that changes in monetary policy often create short run fluctuations on bank health. Thus, regulatory authority must focus on factors such as monetary policy rate and bank capital position in order to attain a significant economic performance through banks serve as a monetary policy transmission mechanism to the economy. Similarly, it revealed that bank loans is more sensitive to monetary policy when bank has a lower capital as banks adjust their loan mix in reaction to monetary policy.

\section{References}

Bernanke B.S., \& Gertler M. (1987). Banking in General Equilibrium. In: Barnett W, Singleton K (eds) New approaches to monetary economics. Cambridge University Press, Cambridge.

Bernanke, B., \& Lown, C. (1991). The Credit Crunch, Brookings Papers on Economic Activity. 0(2).

Bolton, P., \& Freixas, X. (2000). Corporate Finance and the Monetary Policy Transmission

Mechanism, mimeo, University of Pompeu Fabra.

Den Haan W.J., Sumner S.W. \& Yamashiro G.M. (2007). Banks' loan portfolio and the monetary transmission mechanism. Journal of Monetary Economies, 54(3):904-924

Gambacorta L., \& Mistrulli P.E. (2004). Does bank capital affect lending behaviour? Journal of Financial Intermediation, 13:436-457.

Hancock D., \& Wilcox J (1997). Bank capital, nonbank finance, and real estate activity, Journal of Housing Research (Fannie Mae Foundation), 8(1):75-105.

Holmstrom, B., \&Tirole, J. (1997). Financial Intermediation, Loanable funds, and the Real

Sector, Quarterly Journal of Economics, 112(3).

Johansen, S. (1992). Testing weak exogeneity and the order of cointegration in UK money demand data, Journal of Policy Modeling, 14:313-334.

Johansen, S. (1988). Statistical analysis of cointegration vectors, Journal of Economic Dynamics and Control, 12:231-254.

Johansen, S. \& Juselius K. (1990). Maximum likelihood estimation and inference on cointegration: With applications to the demand for money, Oxford Bulletin of Economics and Statistics 52:169-210.

Kishan R.P. \& Opiela T.P. (2006). Bank capital and loan asymmetry in the transmission of monetary policy. Journal of Banking and Finance, 30(1):260-284

Mankiw G. (1986). The allocation of credit and financial collapse. Quarterly Journal of Economics, 101(3):455-470. 
Meh C., \& Moran K. (2004). Bank capital, agency costs, and monetary policy. Bank of Canada Working Paper Orzechowski P.E. (2016) Bank capital, loan activity, and monetary policy: evidence from the FDIC's Historical Statistics on Banking, Journal of Economics and Finance, 10.1007/s12197-016-9359-5

Peek J, \& Rosengren E. (1995). The capital crunch: neither a borrower nor a lender be. Journal of Money, Credit and Banking, 27(3):626-638.

Schneider, M. (1998). Borrowing Constraint in a Dynamic Model of Bank Asset and Liability Management, mimeo, Standford University.

Sims, C. A. (1980). Comparison of interwar and postwar business cycles: Monetarism reconsidered, American Economic Review: Papers and Proceedings 70: 250-257.

Turguttopbas N. (2017) Perspectives on Monetary Policy and Cost of Capital: Evidence from Turkey. Journal of Central Banking Theory and Practice, 2:45-64

Van den Heuvel, S.K. (2002). Does Bank Capital Matter for Monetary Policy Transmission, Federal Reserve Bank of New York Economic Policy Review, May.

\begin{tabular}{|c|c|c|c|c|c|}
\hline \multicolumn{6}{|c|}{ Vector Error Correction Estimates } \\
\hline \multicolumn{6}{|c|}{ Standard errors in ( ) \& t-statistics in [ ] } \\
\hline Cointegrating Eq: & CointEq1 & & & & \\
\hline LOANS(-1) & 1.000000 & & & & \\
\hline \multirow[t]{3}{*}{ MPR(-1) } & 1.339686 & & & & \\
\hline & $(0.17711)$ & & & & \\
\hline & {$[7.56434]$} & & & & \\
\hline \multirow[t]{3}{*}{$\mathrm{LR}(-1)$} & -0.397584 & & & & \\
\hline & $(0.32726)$ & & & & \\
\hline & {$[-1.21489]$} & & & & \\
\hline \multirow[t]{3}{*}{ CAPITAL(-1) } & 0.088802 & & & & \\
\hline & $(0.14776)$ & & & & \\
\hline & {$[0.60097]$} & & & & \\
\hline \multirow[t]{3}{*}{ GDP(-1) } & -1.274915 & & & & \\
\hline & $(0.20448)$ & & & & \\
\hline & {$[-6.23497]$} & & & & \\
\hline $\mathrm{C}$ & 0.912531 & & & & \\
\hline Error Correction: & $\mathrm{D}($ LOANS $)$ & $\mathrm{D}(\mathrm{MPR})$ & $\mathrm{D}(\mathrm{LR})$ & $\mathrm{D}(\mathrm{CAPITAL})$ & $\mathrm{D}(\mathrm{GDP})$ \\
\hline \multirow[t]{3}{*}{ CointEq1 } & 0.041128 & -0.334376 & -0.300722 & 0.353026 & 0.441386 \\
\hline & $(0.08088)$ & $(0.18011)$ & $(0.18708)$ & $(0.31539)$ & $(0.12072)$ \\
\hline & [0.50851] & {$[-1.85653]$} & {$[-1.60743]$} & [ 1.11933] & [ 3.65624] \\
\hline \multirow[t]{3}{*}{$\mathrm{D}($ LOANS(-1)) } & 0.399558 & -0.587514 & -0.341550 & 0.501241 & -0.207379 \\
\hline & $(0.18761)$ & $(0.41778)$ & $(0.43396)$ & $(0.73158)$ & $(0.28003)$ \\
\hline & [ 2.12978] & {$[-1.40628]$} & {$[-0.78706]$} & [0.68514] & {$[-0.74057]$} \\
\hline \multirow[t]{3}{*}{$\mathrm{D}(\operatorname{LOANS}(-2))$} & -0.494362 & 0.229637 & 0.214006 & -1.504182 & 0.146943 \\
\hline & $(0.16711)$ & $(0.37214)$ & $(0.38655)$ & $(0.65167)$ & $(0.24944)$ \\
\hline & {$[-2.95826]$} & {$[0.61707]$} & {$[0.55363]$} & {$[-2.30820]$} & {$[0.58910]$} \\
\hline
\end{tabular}




\begin{tabular}{|c|c|c|c|c|c|}
\hline \multirow[t]{3}{*}{$\mathrm{D}(\mathrm{MPR}(-1))$} & -0.459501 & 0.194152 & 0.696111 & -1.042097 & -0.575158 \\
\hline & $(0.14160)$ & $(0.31533)$ & $(0.32754)$ & $(0.55218)$ & $(0.21136)$ \\
\hline & {$[-3.24506]$} & {$[0.61571]$} & [2.12528] & {$[-1.88724]$} & {$[-2.72128]$} \\
\hline \multirow[t]{3}{*}{$\mathrm{D}(\mathrm{MPR}(-2))$} & -0.202334 & 0.268048 & 0.168325 & -0.601847 & -0.253934 \\
\hline & $(0.11164)$ & $(0.24860)$ & $(0.25823)$ & $(0.43534)$ & $(0.16663)$ \\
\hline & {$[-1.81243]$} & [ 1.07822$]$ & [0.65184] & [-1.38249] & [-1.52392] \\
\hline \multirow[t]{3}{*}{$\mathrm{D}(\mathrm{LR}(-1))$} & 0.161841 & -0.314817 & -0.476456 & 0.643228 & 0.113189 \\
\hline & $(0.11157)$ & $(0.24846)$ & $(0.25808)$ & $(0.43509)$ & $(0.16654)$ \\
\hline & [ 1.45054$]$ & {$[-1.26707]$} & {$[-1.84614]$} & [ 1.47839$]$ & [0.67966] \\
\hline \multirow[t]{3}{*}{$\mathrm{D}(\mathrm{LR}(-2))$} & -0.078638 & -0.131131 & -0.176843 & 0.346130 & 0.012413 \\
\hline & $(0.09567)$ & $(0.21304)$ & $(0.22129)$ & $(0.37306)$ & $(0.14279)$ \\
\hline & {$[-0.82200]$} & {$[-0.61553]$} & {$[-0.79915]$} & [0.92782] & [0.08693] \\
\hline \multirow[t]{3}{*}{ D(CAPITAL(-1)) } & 0.287027 & 0.103985 & 0.143170 & -0.166692 & -0.072256 \\
\hline & $(0.05836)$ & $(0.12997)$ & $(0.13500)$ & $(0.22760)$ & $(0.08712)$ \\
\hline & [ 4.91787] & {$[0.80007]$} & [ 1.06049] & {$[-0.73240]$} & {$[-0.82942]$} \\
\hline \multirow[t]{3}{*}{ D(CAPITAL $(-2))$} & -0.143905 & 0.041788 & 0.318518 & -0.190282 & -0.162946 \\
\hline & $(0.08619)$ & $(0.19193)$ & $(0.19936)$ & $(0.33609)$ & $(0.12864)$ \\
\hline & {$[-1.66970]$} & [0.21773] & [ 1.59770] & {$[-0.56616]$} & {$[-1.26664]$} \\
\hline \multirow[t]{3}{*}{$\mathrm{D}(\mathrm{GDP}(-1))$} & 0.086734 & 0.383677 & 0.135540 & 0.281107 & 0.125848 \\
\hline & $(0.11191)$ & $(0.24920)$ & $(0.25885)$ & $(0.43639)$ & $(0.16704)$ \\
\hline & [ 0.77506$]$ & [ 1.53961$]$ & {$[0.52362]$} & {$[0.64417]$} & {$[0.75342]$} \\
\hline \multirow[t]{3}{*}{$\mathrm{D}(\mathrm{GDP}(-2))$} & 0.068008 & -0.201519 & -0.049747 & 0.150517 & 0.098981 \\
\hline & $(0.10938)$ & $(0.24357)$ & $(0.25300)$ & $(0.42652)$ & $(0.16326)$ \\
\hline & [0.62178] & {$[-0.82736]$} & {$[-0.19663]$} & {$[0.35289]$} & [0.60628] \\
\hline \multirow[t]{3}{*}{$\mathrm{C}$} & 0.085092 & 0.002213 & -0.060215 & 0.235195 & 0.111405 \\
\hline & $(0.02582)$ & $(0.05750)$ & $(0.05973)$ & $(0.10069)$ & $(0.03854)$ \\
\hline & [ 3.29555] & {$[0.03848]$} & {$[-1.00819]$} & [2.33586] & [2.89061] \\
\hline R-squared & 0.766552 & 0.520503 & 0.379727 & 0.288745 & 0.606719 \\
\hline Adj. R-squared & 0.638156 & 0.256779 & 0.038577 & -0.102446 & 0.390414 \\
\hline Sum sq. resids & 0.036728 & 0.182138 & 0.196518 & 0.558519 & 0.081828 \\
\hline S.E. equation & 0.042853 & 0.095430 & 0.099126 & 0.167111 & 0.063964 \\
\hline F-statistic & 5.970209 & 1.973669 & 1.113078 & 0.738118 & 2.804924 \\
\hline Log likelihood & 62.91305 & 37.29356 & 36.07779 & 19.36521 & 50.09583 \\
\hline Akaike AIC & -3.182066 & -1.580848 & -1.504862 & -0.460325 & -2.380989 \\
\hline Schwarz SC & -2.632415 & -1.031197 & -0.955211 & 0.089326 & -1.831338 \\
\hline Mean dependent & 0.100133 & 0.004322 & -0.003489 & 0.117860 & 0.091630 \\
\hline S.D. dependent & 0.071240 & 0.110695 & 0.101095 & 0.159157 & 0.081926 \\
\hline \multicolumn{2}{|c|}{ Determinant resid covariance (dof adj.) } & $9.56 \mathrm{E}-12$ & & & \\
\hline \multicolumn{2}{|c|}{ Determinant resid covariance } & $9.12 \mathrm{E}-13$ & & & \\
\hline \multicolumn{2}{|l|}{ Log likelihood } & 216.5481 & & & \\
\hline \multicolumn{2}{|c|}{ Akaike information criterion } & -9.471753 & & & \\
\hline
\end{tabular}


Appendix B: The Impulse Response
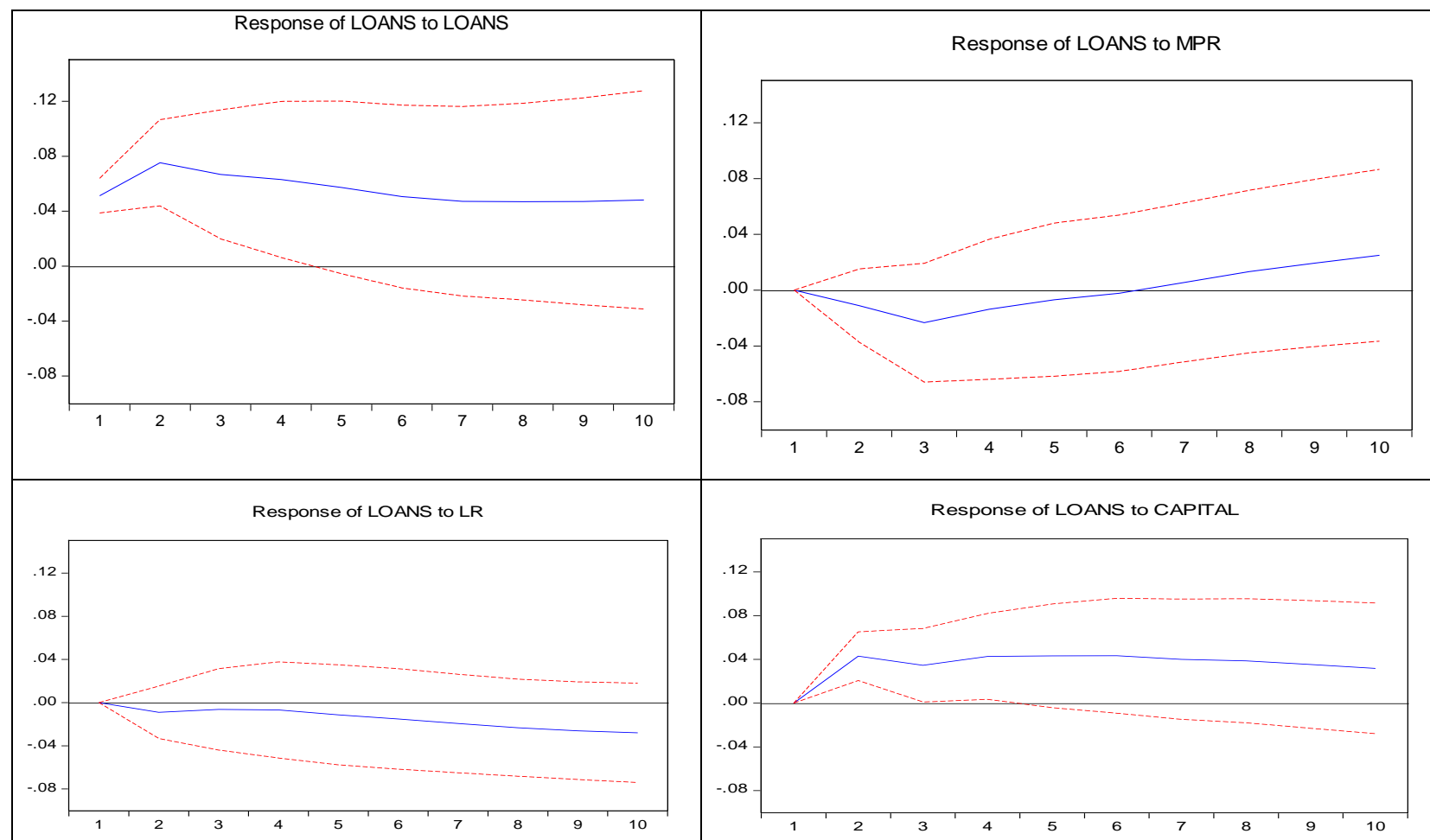

Response of LOANS to CAPITAL
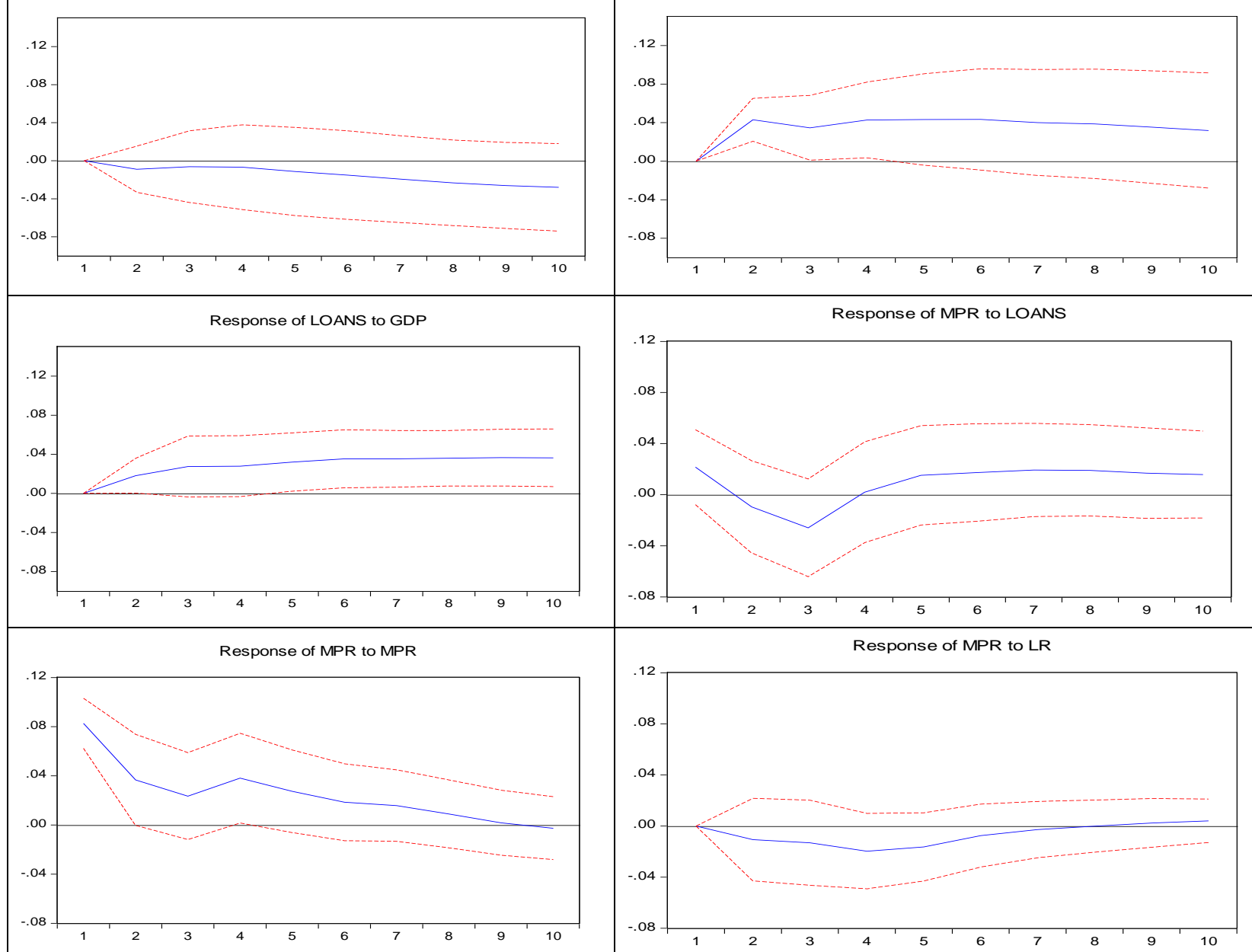


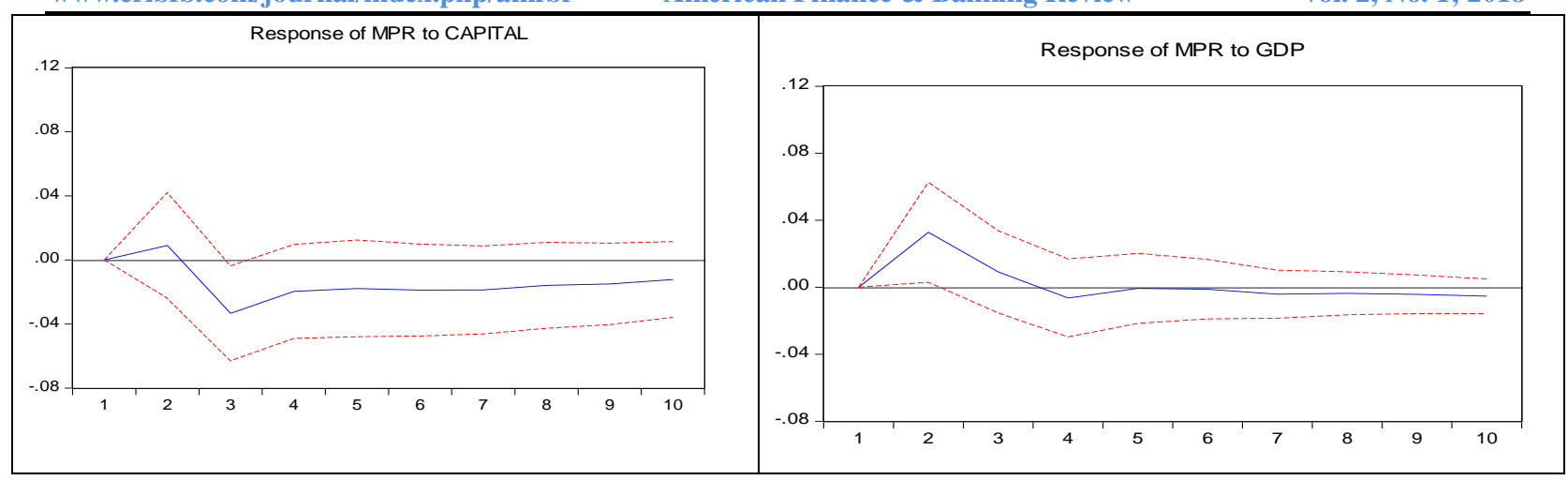

\section{Copyrights}

Copyright for this article is retained by the author(s), with first publication rights granted to the journal.

This is an open-access article distributed under the terms and conditions of the Creative Commons Attribution license (http://creativecommons.org/licenses/by/4.0/). 